\title{
The Inclusive Finance Have Effects on Alleviating Poverty
}

\author{
Dian Jin \\ Jinan University, Guangzhou, China \\ Email:1056708197@qq.com
}

How to cite this paper: Jin, D. (2017) The Inclusive Finance Have Effects on Alleviating Poverty. Open Journal of Social Sciences, 5, 233-242.

https://doi.org/10.4236/jss.2017.53021

Received: February 22, 2017

Accepted: March 26, 2017

Published: March 31, 2017

Copyright $\odot 2017$ by author and Scientific Research Publishing Inc. This work is licensed under the Creative Commons Attribution International License (CC BY 4.0).

http://creativecommons.org/licenses/by/4.0/

\section{(c) (i) Open Access}

\begin{abstract}
Researchers and policy makers are always paying attention to the problems of the development of finance and poverty alleviation. As the development of economic in the world, finance changes for the better day by day, and the availability of financial services increases; for a long time, the financial systems are not perfect in most developing countries and it may cause problems such as the income inequality which results in the growing gap between the rich and poor. For most developing countries, they must face the problem of how to alleviate poverty. Financial development is measured by inclusive finance in this paper but not the scale or efficiency of financial development as before. The aim of this paper is to analyse the relationship between inclusive finance and the gap of rich and poor through the panal data of Asian, African and Latin American countries from 2004 to 2013 by using generalized method of moments method.
\end{abstract}

\section{Keywords}

Inclusive Finance, Alleviating Poverty, Asian, African and Latin American Countries

\section{Introduction}

As the development of the economic and finance in the world, Asia, Africa and Latin America countries also have great growth in these areas. However, the system and social security in these countries are not perfect; the gap between the rich and poor becomes greater. To economy, finance is a great driving force. It is very important to research the relationship between finance and alleviating poverty.

For a long time, the degree of financial development in the world is not uniform, and the availability of financial services varies from region to region. 
Finance can provide services for more people in regions with higher levels of financial development. In regions with low financial development, finance can only provide limited services. Unlike most recent researches focusing on the size and the efficiency of financial development, this paper explores the relationship between financial development and poverty alleviation by inclusive finance, which has significant sense to alleviate poverty and improve the income gap.

Inclusive finance was first proposed by the United Nations in 2005. Sarma, M. and Pais, J. (2011) [1] thinks inclusive finance comes from microcredit, and its main task is to help poor groups gain more opportunities to enjoy more financial services through financial innovations. Mohan, R. (2010) [2] shows the other concept is financial exclusion. Because of the existence of various reasons, not everyone can get services from financial institutions and the development of finance. Due to the existence of higher barriers to financial services, those who have low income are excluded from the traditional financial institutions, and inclusive finance came into being. Ramakrishnan (2010) [3] pointed out that inclusive finance meant to be able to provide suitable, understandable and practical financial services for everyone, which can help poor people get high quality financial services and have positive effects on the development of economy. Yu Yong (2015) [4] thinks that the core of inclusive finance is to have effective services for all people in the society, especially for the people living in rural who are always ignored by the traditional finance, which can help urban and rural poor groups and small and medium enterprises provide equal opportunities for financial services. Shen J. (2015) [5] considered that the development of microfinance system created inclusive finance, and its essence is not only the poor but also the rich should get a common and fair credit rights, and have access to financing channels. And it can reduce the impact of economic risks for poor families. Therefore, the development of inclusive finance can solve the problems of providing higher quality of financial services, benefiting a wider range of people and reducing the cost of financial transactions. Akhter, S., Liu, Y. and Daly K. Shows (2010) [6] the World Bank has made a number of measures to promote the development of inclusive finance, focusing on low-income groups, making the development inclusive finance goals and calling on countries in the world to participate in the activities. Especially, in Asia, Africa and Latin America countries, governments have made a lot of efforts to develop inclusive finance. Thi Thu Tra Pham \& Robert LensinkIn Asia (2009) [7] shows by the commercial banks, rural banks and other formal financial institutions participating in the goal of inclusive finance, Indonesia have provided more financial services to remote and rural areas; by raising the deposit insurance of deposit insurance companies, the central bank provide support and protection for consumers. Bangladesh has entered the field of diversification of financial services in the new field by the traditional microfinance, which have good effects on the financial development. In Africa, Kenya has also reduced the costs of financial services as the rapid growth of mobile banking, and the central bank and financial regulators have also relaxed financial controls and simplified financial institu- 
tion service process. In South America, Brazil has extended its financial services through issuing the reports of inclusive finance, promoting agency banking business models. Thus, government can provide more financial services to low-income families while reducing the costs of financial services. Mexico provides residents with more perfect infrastructure, more financial institutions and modifies the financial legal service system to promote the development of financial policy. Microfinance services have played an important role in the development of inclusive finance, and government should undertake more responsibility.

For the poverty problem, the United Nations show that more than 40 percent of the world's poorest people live in sub-Saharan Africa, where the population growth rate is fast while the economic growth rate is slow, with the frequent natural disasters. In this area, the number of poor people increased from 291 million in 1990 to about 366 million by 2015. South Asia is also a region where live many poor people that account for $34 \%$ of the world's poor. The United Nations stated that the goal of sustainable development is to eliminate poverty in all the world by 2030 , and how to eliminate poverty becomes a problem in the development of the society. In recent years, the fact that the gap between the rich and the poor becomes larger and larger in the world shows the international aid model has failed to play its role and it's time to explore new models to alleviate poverty. Claessens, Stiji, Perotti (2005) [8] pointed that the World Bank and the International Monetary Fund help the poor countries based on the report of the goal of alleviating poverty, which stresses the relations between medium-term goal and long-term goal in Africa. Wang Chen \& Takuji Kinkyo (2006) [9] pointed out that the Latin American countries have the problems of large gap between rich and poor, the high percentage of the poverty-stricken population in a long time. Latin American countries generally choose to increase social spending, especially healthy spending in order to create a harmonious social environment to solve these problems. Franklin, Allen, Isaac, Otchere, LemmaW, Senbet (2011) [10] pointed out that, for the problem of high inflation in the last century, Latin American countries take many measures in order to have stable macroeconomic to protect the real purchasing power of low-income people. At the same time, remittances become an important factor in alleviating poverty. However, the low economic growth rate, the severe employment situation, the high percent of the poverty-stricken population and the large gap between the poor and the rich are the main constraints which Latin American countries need to face.

\section{Inclusive Finance Development and Poverty Alleviation of the Empirical Analysis}

Based on the previous analysis and the existing theory, we have adopted the following measurement models for Asia, Africa and Latin American countries in order to analyze the relationship between the development of inclusive finance and the poverty alleviation in Asia, Africa and Latin America: 


$$
\begin{aligned}
\text { poverty }_{i, t, c}= & a_{1}+a_{2} \text { finance }_{i, t, c}+a_{3} \text { finance }_{i, t, c}^{2}+a_{4} \text { government }_{i, t, c} \\
& +a_{5} \text { infilation }_{i, t, c}+a_{6} \text { gdp }_{i, t, c}+a_{7} \text { trade }_{i, t, c}(c=1) \\
& +a_{8} \text { source }_{i, t, c}(c=2)+a_{9} \text { structure }_{i, t, c}(c=3)+e
\end{aligned}
$$

Among them, $i$ means different countries, $t$ means the year, if $c$ is 1 , it means Asia, if $c$ is 2, it means Africa, if $c$ is 3, it means Latin American countries, $e$ means error terms.

poverty $_{i, t, c}$ means poverty, for the inequality index, the gap between the poor and rich with the absolute indicators existing defects, so this paper use relative indicators, the Gini coefficient is adopted in the world. The greater the Gini coefficient, the greater the income gap is; the smaller the Gini coefficient, the smaller the income gap is.

finance $_{i, t, c}$ means the development of inclusive finance, $a_{2}$ is the coefficient of finance $_{i, t, c}$, and $a_{3}$ is the coefficient of finance $_{i, t, c}^{2}$, if $a_{2}$ is not equal 0 but $a_{3}$ is 0 , it means the linear relation between inclusive finance and poverty alleviation: if $a_{2}$ is less than 0 , it means the development of inclusive finance will alleviate poverty; if $a_{2}$ is greater than 0 , it means the development of inclusive finance will widen the gap of the poor and rich. If both $a_{2}$ and $a_{3}$ are not equal 0 , it means there is no linear relation between inclusive finance and poverty alleviation: if $a_{3}$ is less than 0 , it means the development of inclusive finance will widen the income gap of the poor and rich firstly, then this income gap will narrow after a long time, which is good for alleviating poverty; if $a_{3}$ is greater than 0 , it means the development of inclusive finance will narrow the income gap of the poor and rich firstly, then this income gap will widen after a long time, which is bad for alleviating poverty. As for the most of developing countries in Asia, Africa and Latin America, economic and financial development is still relatively undeveloped, banks control the financial and they have short history of the concept of inclusive finance, not yet a generally common measurement standards of inclusive finance, no current data to research it. Therefore, this article's inclusive finance development indicators are calculated by myself from the bank point of view, the greater the index is, the higher level of the development of inclusive finance.

According to the International Monetary Fund, the indicators of inclusive finance are divided into two parts which are availability and usability. The availability of inclusive finance is described in terms of the population dimension and the usability is described in terms of the geographic dimension. In this paper, the population dimension is determined on the average of the number of bank branches and ATMs per 100,000 people; the geographic dimensions is calculated from the average number of bank branches and the number of ATMs per thousand square kilometers of land. The usability of inclusive finance is determined by loans from banks per person. After normalizing the five different dimensions of the original data, making it a unified value between 0 - 1 , which represent the population dimension, the geographical dimension and availability of credit resources. inclusive finance indicators are derived on the average of 
these three aspects.

As Asian countries like export-oriented economy, this paper join the trade as another explanatory variable. The import and export trade of goods and services represents one country's openness and it is one of the signs of the level of market development. Import and export trade may have two different impacts on the income gap between rich and poor: on the one hand, the development of foreign trade brought foreign exchange, which promotes the country's economic development and help narrow the income gap; on the other hand, foreign trade may promote the process of industrialization, resulting unfair distribution of income.

As African countries have rich natural resources, natural resources are included in the African region as another explanatory variable. We can image that the increase of the usage of natural resources can increase people's income and then alleviate poverty.

Latin American countries in the last century have currency crisis, problems of inflation and middle income trap, they try to solve the problems by upgrade the industrial structure to improve economic development, increase income and narrow the income gap, then upgrading the industrial structure becomes another explanatory variable in this area. According to the law of the evolution of the industrial structure, tertiary industry is more and more important, and primary industry is relatively reduced. Therefore, when measuring the level of upgrading industrial in Latin America, The proportion of the total output value of the primary industry is multiplied by 1 , the proportion of the output value of the secondary industry is multiplied by 2 , the proportion of the output value of the tertiary industry is multiplied by 3 , then we can plus this three parts which is the index of upgrading industry, the lower of the index, the lower level of the industry, the higher of the index, the higher level of the industry.

This paper refers to the following indicators as control variables: 1) Government expenditure. The government's tax and transfer payments to the low-income class will affect the income gap of a country, which leads to a redistribution of income for a country, and it can narrow the income gap between the rich and the poor and alleviate poverty, so we can image the coefficient is negative; 2 ) Per capita GDP. Per capita GDP can measure economic growth, help narrow the gap between rich and poor to a certain extent, poverty alleviation, so the index is expected to be negative. The Kuznets curve, which reflects the relationship between economic growth and income inequality, is an inverted U-state, indicating that income inequality is deteriorating with economic growth when the per capita income level is low. Once the per capita income level exceeds a certain level, The income inequality will gradually ease, the gap between rich and poor will shrink; 3) Inflation rate. Inflation is directly related to the standard of living of the people, and the high price will lower the the quality of life to a certain extent, especially for the low-income class, which is bad to alleviate poverty, so the coefficient is expected to be positive.

In order to reduce the influence of the endogeneity of the variables, the generation of heteroscedasticity and the excessive fluctuation of the data, the paper 
take the natural logarithm of all the relevant variables to improve the robustness of the econometric analysis.

Asia, Africa and Latin America are poor regions in the world, they have some different characteristics in some areas. The following part will divide Asia, Africa and Latin America into three regions to check the relationship between inclusive finance and poverty alleviation. Maybe we can find something different. And finally with all countries in Asia, Africa and Latin America, we carry out relationship between inclusive finance and poverty alleviation.

Considering the availability of data, this paper examines the relationship between inclusive finance and poverty alleviation of 24 countries in Asia, 32 in Africa and 30 in Latin America. The time dimensions of all the countries are during the decade of 2004-2013, with data from the World Bank. The following four tables are the main variable definitions and statistical characteristics for all countries in Asia, Africa, Latin America and Asia and Africa. The statistical characteristics are shown in Tables 1-3.

Since this paper is concerned with the study of the development of inclusive finance and poverty alleviation in Asia, Africa and Latin America between 2004 to 2013 , it is a short panel data, which is easy to produce endogenous problems. Therefore, to avoid estimating bias, this paper adopts the system generalized method of moments method, and use lagged independent variable as a tool variable, which is effective to test.

Because of the heteroscedastic problem, the traditional Hausman test is not suitable for the fixed effect model or the stochastic effect model. After constructing the auxiliary regression, the original hypothesis is strongly rejected, and the fixed effect model should be used, and the model is modeled by Robust.

Table 1. Definition and statistical characteristics of main variables in Asian countries.

\begin{tabular}{|c|c|c|c|c|c|c|}
\hline variable & Definition & Observations & mean & \multicolumn{3}{|c|}{ Standard deviation minimum maximum } \\
\hline finance & inclusive finance & 240 & 0.446502 & 0.4261209 & 0.0000564 & 0.9980333 \\
\hline governmen & rernment expenditure & 240 & 13.05253 & 4.618828 & 3.460335 & 25.87842 \\
\hline trade & Trade & 240 & 91.34879 & 38.45446 & 0.3088029 & 210.3738 \\
\hline inflation & Inflation rate & 240 & 6.776031 & 5.902557 & -18.1086 & 36.7023 \\
\hline gdp & Per capita GDP & 240 & 9986.263 & $17,576.16$ & 224.9147 & 0.96077 \\
\hline poverty & gini & 240 & 36.15966 & 5.82175 & 16.23 & 46.26 \\
\hline
\end{tabular}

Table 2. Definition and statistical characteristics of main variables in African countries.

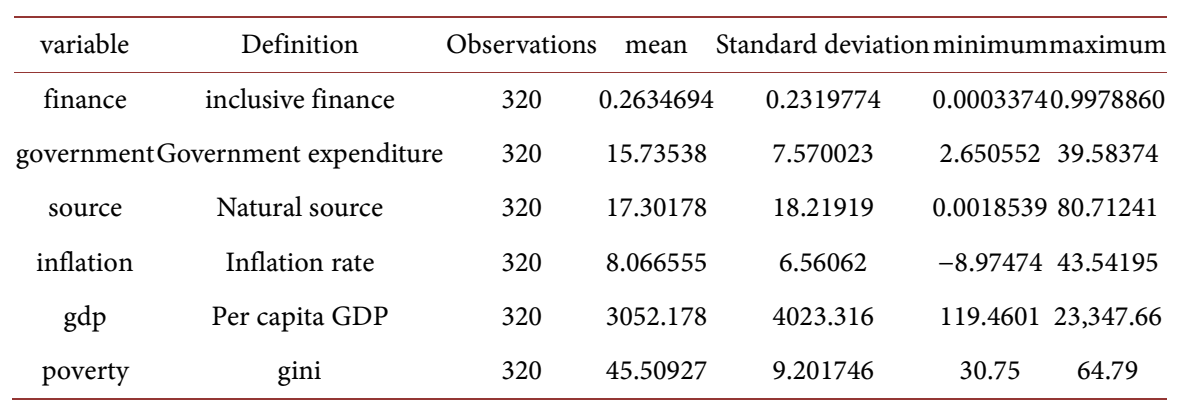


The results are shown in the table below.

There are many variables are not statistically significant when it comes to the relationship between inclusive finance and poverty alleviation in Asia, Africa and Latin America during 2004-2013, and the endogenous test shows that the panel data exists endogenous problems. Then using lag variables as tool variables and the method of generalized method of moments estimation, which have been proved effective by the results of Hansen test and AR (2) test.

As shown in Table 4, on the whole, there is a linear negative correlation between the development of inclusive finance and poverty alleviation in the countries of Asia, Africa and Latin America.

When it comes to finance ${ }^{2}$, the coefficient of Asian countries $a_{2}$ is statistically significant, while it is not significant for $a_{3}$, which indicates that there is a negative correlation between the development of inclusive finance and poverty

Table 3. Definition and statistical characteristics of main variables in Latin American countries.

\begin{tabular}{ccccccc}
\hline variable & Definition & \multicolumn{2}{c}{ Observations } & mean & \multicolumn{2}{c}{ Standard deviation minimum maximum } \\
\hline finance & inclusive finance & 300 & 0.263469 & 0.2319774 & 0.0001382 & 0.939351 \\
government & Government expenditure & 300 & 14.2049 & 3.55777 & 6.207438 & 27.24494 \\
structure & Industrial structure & 300 & 2.401131 & 0.5705723 & 0 & 2.806157 \\
inflation & Inflation rate & 300 & 6.032926 & 5.759335 & -3.65348 & 51.46086 \\
gdp & Per capita GDP & 300 & 6835.572 & 4472.998 & 387.9427 & $21,188.09$ \\
poverty & gini & 300 & 51.29541 & 4.172673 & 40.49 & 60.79 \\
\hline
\end{tabular}

Table 4. The relationship between inclusive finance and poverty alleviation.

\begin{tabular}{|c|c|c|c|c|c|c|c|c|}
\hline & Asian 1 & Asian 2 & Africa 1 & Africa 2 & Latin America 1 & Latin America 2 & countries 1 & countries 2 \\
\hline finance & $\begin{array}{c}-0.013753 \\
(-0.57)\end{array}$ & $\begin{array}{c}-0.013632^{\star} \\
(-1.88)\end{array}$ & $\begin{array}{c}-0.001660 \\
(-0.9)\end{array}$ & $\begin{array}{c}-0.0012819 \\
(-1.21)\end{array}$ & $\begin{array}{c}-0.013177 \\
(-1.1)\end{array}$ & $\begin{array}{c}-0.016003 \\
(-0.46)\end{array}$ & $\begin{array}{c}-0.0007564 \\
(-0.48)\end{array}$ & $\begin{array}{c}-0.0011664^{*} \\
(-1.62)\end{array}$ \\
\hline finance $^{2}$ & & $\begin{array}{c}0.0058185 \\
(1.02)\end{array}$ & & $\begin{array}{c}7.93 \mathrm{e}-06 \\
(0.03)\end{array}$ & & $\begin{array}{c}-0.00125^{*} \\
(-2.26)\end{array}$ & & $\begin{array}{c}-0.0001318 \\
(-0.77)\end{array}$ \\
\hline government & $\begin{array}{c}0.0107078 \\
\quad(1.43)\end{array}$ & $\begin{array}{c}0.0141842 \\
(1.55)\end{array}$ & $\begin{array}{c}-0.0024726 \\
(-0.62)\end{array}$ & $\begin{array}{c}-0.003568 \\
(-0.84)\end{array}$ & $\begin{array}{c}0.0098348 \\
(0.4)\end{array}$ & $\begin{array}{c}0.0121836 \\
(0.45)\end{array}$ & $\begin{array}{c}0.0024343 \\
(0.31)\end{array}$ & $\begin{array}{c}0.0026844 \\
(0.34)\end{array}$ \\
\hline gdp & $\begin{array}{c}-0.003822 \\
(-0.87)\end{array}$ & $\begin{array}{c}-0.003515^{\star \star} \\
(-2.10)\end{array}$ & $\begin{array}{c}-0.0000678 \\
(-0.04)\end{array}$ & $\begin{array}{c}0.0004284 \\
(0.17)\end{array}$ & $\begin{array}{c}-0.022374^{\star} \\
(-1.92)\end{array}$ & $\begin{array}{c}-0.026199 \\
(-1.32)\end{array}$ & $\begin{array}{c}-0.0000725 \\
(-0.03)\end{array}$ & $\begin{array}{c}-0.0000555 \\
(-0.03)\end{array}$ \\
\hline inflation & $\begin{array}{c}-0.012138 \\
(-1.31)\end{array}$ & $\begin{array}{c}-0.019488 \\
(-1.59)\end{array}$ & $\begin{array}{c}0.0020623 \\
(0.54)\end{array}$ & $\begin{array}{c}0.0023995 \\
(0.63)\end{array}$ & $\begin{array}{c}-0.005543 \\
(-0.53)\end{array}$ & $\begin{array}{c}-0.004310 \\
(-0.47)\end{array}$ & $\begin{array}{c}0.0004185 \\
(0.12)\end{array}$ & $\begin{array}{c}0.0003985 \\
(0.12)\end{array}$ \\
\hline trade & $\begin{array}{l}0.0082057 \\
\quad(0.26)\end{array}$ & $\begin{array}{c}0.0090258^{*} \\
(1.81)\end{array}$ & & & & & & \\
\hline source & & & $\begin{array}{c}-0.0013053 \\
(-0.83)\end{array}$ & $\begin{array}{c}-0.0015333^{*} \\
(-1.8)\end{array}$ & & & & \\
\hline structure & & & & & $\begin{array}{c}-0.551235 \\
(-1.55)\end{array}$ & $\begin{array}{c}-0.487470^{*} \\
(-1.81)\end{array}$ & & \\
\hline _cons & $\begin{array}{c}0.4739101^{\star * *} \\
(9.06)\end{array}$ & $\begin{array}{c}0.4739101^{\star * *} \\
(9.01)\end{array}$ & $\begin{array}{c}-0.1326306^{\star * *} \\
(3.5)\end{array}$ & $\begin{array}{c}-0.0997986^{\star * *} \\
(15.28)\end{array}$ & $\begin{array}{c}4.240465^{\star * *} \\
(12.34)\end{array}$ & $\begin{array}{c}3.954374^{\star * *} \\
(6.68)\end{array}$ & $\begin{array}{c}0.0152895^{\star * *} \\
(4.09)\end{array}$ & $\begin{array}{c}0.0150862^{\star * *} \\
(4.09)\end{array}$ \\
\hline Hansen & 0.98 & 0.97 & 0.763 & 0.808 & 0.999 & 0.999 & 0.76 & 0.87 \\
\hline $\mathrm{AR}(2)$ & 0.217 & 0.234 & 0.485 & 0.665 & 0.691 & 0.668 & 0.853 & 0.856 \\
\hline
\end{tabular}


alleviation. With the development of inclusive finance, the poverty gap in Asian countries will gradually decrease; the coefficient of per capita GDP is statistically significant and the coefficient is negative, indicating that with the development of inclusive finance, it can gradually narrow the income gap in Asian countries, which is consistent with our previous speculation; However, although the Asian countries have promoted export-oriented economic development, the export trade index is not statistically significant, we can not know its role in alleviating poverty.

For African countries, no matter $a_{2}$ or $a_{3}$, they are not statistically significant. It shows that we can not judge the relationship between the development of inclusive finance and poverty mitigation.

For Latin American countries, When it comes to finance ${ }^{2}, a_{3}$ is statistically significant and negative, which indicates that the development of inclusive finance and poverty alleviation have a clear inverted U-type relationship in Latin American countries, the development of financial inclusion expand the income gap between the poor and rich but not narrow the gap. In the early stages of economic development, the level of financial development was low, and the poor were unable to get a variety of financial services because they could not afford a relatively high cost. Such groups were excluded from financial markets and only a small number of people are willing to pay a relatively high cost to enjoy financial services, then these people's incomes increase, so the income gap between the rich and poor rich and poor will expand, therefore, the Gini coefficient rise; when the financial level reaches a high stage after development, with the improvement of the level of financial services, as well as the poor's gradual accumulation of wealth, they get access to enjoy more financial services, no matter the poor or the rich can get financial services by investment, then we can alleviate income inequality gradually, and narrow the income gap between the rich and poor with the financial development, which showed a decline in the Gini coefficient, and finally we can alleviate poverty. During the time, the Gini coefficient increases firstly and then decreases finally. This is consistent with the results we guessed.

When it comes to the index of trade, the coefficient of the adjusted trade indicator is statistically significant and positive, indicating that trade has widened the income gap.

After adding the indicator of natural resources, the indicator is statistically significant but positive, indicating that the usage of natural resources will certainly have an impact on the poverty alleviation of African countries, but this effect is not what we have guessed before. Natural resources have not improved the life of Africa, or reduced the poverty rate, but will expand poverty.

After adding the indicator of industrial structure, the indicator is statistically significant and negative, indicating that the adjustment and upgrading of industrial structure will play a role in the poverty alleviation in Latin American countries. With the development of the adjustment and upgrading of industrial structure, we can narrow the income gap and alleviate poverty. 


\section{Conclusions and Policy Recommendations}

This paper examines the relationship between the development of inclusive finance and poverty alleviation in a total of 86 countries in Asia, Africa and Latin America from 2004 to 2013. Based on the results of the estimation, we can get the following conclusions.

The impact of the development of inclusive finance on poverty alleviation represented by the Gini coefficient is different in Asia, Africa and Latin America. For Asian countries, the development of inclusive finance is negatively correlated with poverty alleviation. With the development of inclusive finance, it can narrow the income poverty between the rich and poor; for African and Latin American countries, there is a clear inverted U-shaped relationship between the development of inclusive finance with poverty alleviation, which indicates that the development of inclusive finance will first widen income gap, and when the financial development reaches a high stage, it can also narrow the income gap, and finally alleviate poverty.

Although the economic development of Asian countries is characterized by export orientation, the export trade indicators are not statistically significant; we can not judge its role in poverty alleviation.

The usage of natural resources in African countries indeed has an impact on poverty alleviation, but this effect is not what we have guessed before; the usage of natural resources can not raise the standard of living in Africa or alleviate poverty.

The adjustment and upgrading of the industrial structure of Latin American countries will indeed play a role in poverty alleviation; with the adjustment and upgrading of industrial structure in Latin America, it can alleviate poverty and narrow income gap in this region.

Government spending can narrow the income gap and alleviate poverty to a certain extent, but the coefficients are not significant in all countries.

There is a linear negative correlation between per capita GDP and poverty alleviation, that is, when per capita GDP increases, it can alleviate poverty and narrow income gap.

In theory, when inflation rate becomes higher and higher, it will widen the income gap between the poor and rich, but in this paper the coefficient of inflation rate is not significant.

Therefore, this paper argues that in order to narrow the income gap between the rich and the poor and alleviate poverty, the first is to promote the development of inclusive finance, improve the financial system which consist of the banking system, insurance, securities and derivative financial products; eliminate barriers and let middle and low-income class get access to financial services; let the inclusive finance play a role in improving financial availability and service capacity. Although in the early stages of economic development, the level of financial development was low, and the poor were unable to get a variety of financial services, and the income gap between the rich and poor rich and poor will expand, therefore; when the financial level reaches a high stage after develop- 
ment, with the improvement of the level of financial services, as well as the poor's gradual accumulation of wealth, they get access to enjoy more financial services, no matter the poor or the rich can get financial services by investment, then we can alleviate income inequality gradually, and narrow the income gap between the rich and poor with the financial development.

\section{References}

[1] Sarma, M. and Pais, J. (2011) Financial Inclusion and Development. Journal of International Development, 23, 613-625. https://doi.org/10.1002/jid.1698

[2] Mohan, R. Economic Growth, Financial Deepening and Financial Inclusion. http://rbidocs.rbi.org.in/rdocs/Speeches/PDFs/73697.pdf

[3] Ramakrishnan, Dr. BFSI: Best Practices in Financial Inclusion. http://ssrn.com/abstract $=1751020$

[4] Yu, Y. (2015) The Development of Inclusive Finance. Journal of Finance Research, 53-60.

[5] Shen, J. (2006) Estimating Urbanization Levels in Chinese Provinces in 1982-2000. International Statistical Review, 74, 89-107. https://doi.org/10.1111/j.1751-5823.2006.tb00163.x

[6] Akhter, S., Liu, Y. and Daly, K. (2010) Cross Country Evidence on the Linkages between Financial Development and Poverty. International Journal of Business and Management, 5, 3-19.

[7] Pham, T.T.T. and Lensink, R. Is Microfmance an Important Instrument for Poverty Alleviation? The Impact of Microcredit Programs on Self-Employment Profits in Vietnam.

[8] Claessens, S. and Perotti, E. (2007) Finance and Inequality: Channels and Evidence. Journal of Comparative Economics, 35, 748-773.

[9] Chen, W. and Kinkyo, T. (2016) Financial Development and Income Inequality: Long-Run Relationship and Short-Run Heterogeneity. Emerging Markets Finance and Trade, 52, 733-742. https://doi.org/10.1080/1540496X.2016.1116281

[10] Franklin (2011) African Financial Systems: A Review. Review of Development Finance, 1-35.

\section{Submit or recommend next manuscript to SCIRP and we will provide best service for you:}

Accepting pre-submission inquiries through Email, Facebook, LinkedIn, Twitter, etc. A wide selection of journals (inclusive of 9 subjects, more than 200 journals)

Providing 24-hour high-quality service

User-friendly online submission system

Fair and swift peer-review system

Efficient typesetting and proofreading procedure

Display of the result of downloads and visits, as well as the number of cited articles

Maximum dissemination of your research work

Submit your manuscript at: http://papersubmission.scirp.org/

Or contact jss@scirp.org 